\title{
Podziały etniczne i narodowościowe w Republice Mołdawskiej. Wpływ i znaczenie edukacji w dwóch odrębnych państwach - Gagauzji i Naddniestrzu
}

KEY WORDS

nationality, ethnicity, autonomy, education, the importance

\begin{abstract}
Kasprzak Tomasz, Podziały etniczne i narodowościowe w Republice Mołdawskiej. Wpływ i znaczenie edukacji w dwóch odrębnych państwach - Gagauzji i Naddniestrzu [Ethnic and National Divisions in the Republic of Moldova. The Impact and Significance of Education in the Two Separate States - Gagauzia and Transnistria]. Kultura - Społeczeństwo - Edukacja nr 1(7), 2015, Poznań 2015, pp. 149-158, Adam Mickiewicz University Press. ISBN 978-83-232-2944-5. ISSN 23000422

Moldova is a country of many paradoxes. three state capitals, located on the territory of the historical Bessarabia. I wanted to conclude the problem of Moldova's national identity and its impact on education today, especially in the autonomous territories: Gagauzia and Transnistria. Moldova is split between: the East - growing power of Russia with her influence in Transnistria and the West - the European Union and Romania. Therefore, the issue of education in Moldova is due to bilingualism and dual citizenship. Lack of an official language makes it difficult to make reforms in education. Moldova in education, is trying to emphasize the uniqueness of national and ethnic.
\end{abstract}

Republika Mołdawska opuściła Związek Socjalistycznych Republik Radzieckich (ZSRR) i odzyskała niepodległość 27 sierpnia 1991 roku. Minęło już 25 lat od tego wydarzenia, a coraz więcej specjalistów zajmujących się problematyką byłych republik radzieckich sygnalizuje, iż kraj ten od wielu lat „stoi w martwym punkcie”. Droga Mołdawii „ku normalności” coraz częściej przypomina pasmo porażek, wzajemnych oskarżeń i pretensji. Ten niewielki kraj na południowym 
wschodzie Europy jest idealnym przykładem ścierania się ogromnych sił ekonomicznych, politycznych oraz społeczno-kulturowych.

Upadek Mołdawskiej Socjalistycznej Republiki Radzieckiej dla wielu obywateli oznaczał nową nadzieję, szansę na zmianę dla kraju wolnego od wpływów Moskwy, zakończenie pewnego etapu. Jednakże rzeczywistość okazała się o wiele bardziej brutalna. Odłączenie od ZSRR, a w rezultacie ogłoszenie niepodległości przez Republikę Mołdawską wzbudzało wiele pytań, często dość kontrowersyjnych. Najwięcej kontrowersji wzbudza ustanowiona 27 sierpnia 1991 roku Deklaracja Niepodległości Republiki Mołdawii. Stopniowo stała się celem „samym w sobie". Wywołała bardzo szybkie ochłodzenie entuzjazmu obywatelskiego, silnie zdeterminowała konflikt pomiędzy rosnącą w siłę partią neokomunistyczną a partiami prokremlowskimi. Rezultatem okazał się powrót starej nomenklatury, jeszcze sprzed powstania niepodległej Mołdawii w 1991 roku (Ciobanu, 2013: 169-170).

\section{Romania este partia mea}

Językiem urzędowym w Republice Mołdawii jest mołdawski. Paradoksem na skalę światową jest fakt, iż żaden z mieszkańców tego niewielkiego kraju nie potrafi się nim posługiwać. Mołdawski uznawany jest przez lingwistów za tożsamy z językiem rumuńskim lub traktowany jako dialekt rumuńskiego. Nie traktuje się go jak odrębny, gdyż podobnie jak rumuński oparty jest na alfabecie łacińskim. Także nazwa języka budzi duże kontrowersje - często przez Mołdawian określany jako „język państwowy”, „nasz język”. Jest to jeden z powodów, dla których coraz częściej możemy zauważyć ścieranie się „mołdawianistów” i „unionistów”. Zważywszy na wspólną historię, Mołdawia zawsze przez Rumunię traktowana będzie ze szczególnym uprzywilejowaniem. Historia obu krajów związana jest przede wszystkim z powstaniem Besarabii w 1812 roku, a potem przynależnością do Wielkiej Rumunii² (lata 1918-1940), co spowodowało szczególny charakter stosunków pomiędzy Bukaresztem a Kiszyniowem. Rumuni zawsze z sentymentem wspominają Besarabię, w ich świadomości Mołdawianie nie są traktowani jako odrębny naród, lecz jako „Rumunii besarabscy” (Pieńkowski, 2013: 152$-154)$.

\footnotetext{
${ }^{1}$ Rumunia to moja ojczyzna.

${ }^{2}$ Okres przynależności Besarabii do Wielkiej Rumunii (1918-1940) cechuje się dużą brutalnością, biedą, wysokim bezrobociem, korupcją oraz dużym zaniedbaniem tejże ludności. Symbolem jest wielki kryzys w 1929 roku. Szczególnie lata 30. XX wieku były zdominowane dużym niepokojem wśród społeczeństwa rumuńskiego oraz mołdawskiego.
} 
Mołdawianie podobnie - traktują Rumunię z dużym uprzywilejowaniem. Dzieje się tak za sprawą wstąpienia Rumunii do Unii Europejskiej (2007), a także dzięki uproszczonej procedurze nadawania obywatelstwa etnicznym Rumunom, mieszkającym w Mołdawii. „Rumuni rozdają obywatelstwa Mołdawianom”. To właśnie Rumunia w 1991 roku, jako pierwszy kraj na świecie, uznała niepodległość Mołdawii. Poruszając problematykę relacji Rumunii z Mołdawią, należy postawić pytanie: „Ile Rumunii w Mołdawii?”. Hasła zjednoczeniowe Rumunii z Mołdawią cieszą się dużą popularnością w rumuńskim społeczeństwie. Pod koniec 2013 roku były prezydent Rumunii Traian Băsescu w jednym z wywiadów telewizyjnych opowiedział się za przyłączeniem Mołdawii do Rumunii. Poparł on swoją tezę następującym argumentami: wstąpieniem Rumunii do NATO i Unii Europejskiej. W związku z tym, według byłego prezydenta, głównym projektem politycznym Rumunii powinno być zjednoczenie z Mołdawią. Wydarzenie to miało miejsce przed szczytem Partnerstwa Wschodniego w Wilnie (2013), a także silnie zakorzenionym $\mathrm{w}$ tożsamości mieszkańców Rumunii świętem Zjednoczenia Rumunii (1 grudnia).

Edukacja w Mołdawii ma silny związek z tożsamością etniczną oraz podwójnym obywatelstwem. Szkoły rumuńskie w Mołdawii funkcjonowały do 1865 roku (Wojny Krymskiej). Ich zamknięcie spowodowane były nasilonym procesem rusyfikacji. Współcześnie $\mathrm{w}$ szkołach istnieje język rumuński, traktowany jako przedmiot obowiązkowy. W związku z postępującym procesem rusyfikacji w latach 70. XX wieku jedna rosyjskojęzyczna klasa przypadała na trzy mołdawskojęzyczne ${ }^{35}$. Ważne do podkreślenia jest, iż rosyjskojęzyczne szkolnictwo w Mołdawii dominuje przede wszystkim w dużych miastach. Problematyka edukacji w Mołdawii związana jest $\mathrm{z}$ brakiem aktualnych danych statystycznych na temat osób „dwujęzycznych” czy posiadających podwójne obywatelstwo. Przykładem mogą być Bułgarzy oraz Ukraińcy, którzy w Mołdawii prowadzą nauczanie w swoim rodzimym języku.

Doktorantka Szkoły Nauk Społecznych Instytutu Filozofii i Socjologii PAN Natalia Sineava-Pankowska opisuje trzy modele tożsamości narodowych, które ścierają się w Mołdawii i mają wpływ na współczesną edukację w tym kraju:

- Panrumunizm: Romania este partia mea. W wymiarze mołdawskim zbudowany jest na podstawie etnicznej i językowej więzi. Język mołdawski traktowany jako dialekt, bezpośrednio związany z językiem rumuńskim. Mołdawianie natomiast są traktowani jako część składowa narodu rumuńskiego. Krytykuje, a tym samym nie akceptuje, odrębnej mołdawskiej historii i literatury. Jest ona nieodłączną częścią Rumunii. Państwo powinno się zająć rozpowszechnieniem kultury i historii rumuńskiej. Więź Rumunii z Mołdawią określają jako tzw. „ge-

\footnotetext{
${ }^{3}$ Oficjalna strona internetowa Józefa Darskiego - Jerzego Targalskiego www.jozefdarski.pl/6974kwestia-besarabska-1993 (dostęp: 10.11.2014).
} 
netyczne pokrewieństwo". Panrumunizm, silnie akcentowany w szkolnym systemie edukacyjnym, nawiązuje do istnienia Wielkiej Rumunii. Powstał on na podstawie szerzącej się propagandy, ukształtowanej na podstawie podobieństw obu krajów. Objęcie prezydentury przez Băsescu (2004-2014) znacznie uaktywniło poczucie tożsamości rumuńskiej wśród mieszkańców Mołdawii.

- Pansłowianizm - sowietyzm: bardzo silnie akcentowany w latach 1940-1989, szczególnie przez komunistów, związany z utworzeniem Mołdawskiej Socjalistycznej Republiki Radzieckiej. Jego głównym założeniem była integracja mieszkańców Mołdawii z resztą ludności Związku Radzieckiego. Poczucie przynależności do radzieckiej kultury i edukacji. Współcześnie, ten rodzaj tożsamości można najsilniej zaobserwować w Naddniestrzu. Silnie narastająca rusyfikacja szkolnictwa mołdawskiego.

- Mołdawianizm: „Mołdawska Mołdawia” czy „Jeden naród, dwa państwa”. Silnie akcentuje narodową i etniczną wyjątkowość Mołdawii. Wyjątkowość polegającą na odrębności historycznej (postać Stefana Wielkiego) a także rozwoju społeczno-kulturowego. Z założenia mołdawianizm ma dwa podstawowe typy: rdzenny i wieloetniczny. Sytuację komplikuje wewnętrzne rozdarcie kraju pomiędzy Wschodem a Zachodem. Najważniejszym celem jest chronienie niezależności kraju Mołdawskiego i skoncentrowanie wokół proeuropejskiego kursu politycznego (Sineava-Pankowska, 2009, s. 65-70).

\section{Gagauzja - ambicje narodowościowe kontra rzeczywistość}

Autonomiczna Jednostka Terytorialna Gagauzja jest specjalnym obszarem administracyjnym leżącym w południowej Mołdawii. Utworzono ją w 1994 roku w ramach Republiki Mołdawskiej. Zajmuje około 5\% powierzchni rumuńskojęzycznej Mołdawii, w większości zamieszkanej przez Gagauzów, posługujących się własnym językiem gagauskim (należy do grupy języków tureckich). Współcześnie nie potrafimy jednoznacznie określić ich pochodzenia. Stolicą jest Komrat.

Przed ogłoszeniem specjalnego statusu w 1994 roku Gagauzja nie miała żadnego specjalnego statusu w ramach Mołdawskiej Socjalistycznej Republiki Radzieckiej. Próba uzyskania odpowiedzi na pytanie „kim są Gagauzi?” jest niewątpliwie trudna. Oni sami określają się mianem „sturczonych Bułgarów” lub „zbułgarzonych Turków”. Pozostaje nam głównie spekulacja, gdyż część mieszkańców Gagauzji uważa się za potomków Turków, inni za Karakałpaków, spotkać można także potomków Bułgarów czy Rosjan. W większości deklarują prawosławie (Solak, 2009: 75-76).

W wyniku wzrostu separatyzmu (szczególnie w Naddniestrzu) oraz istniejącej możliwości przyłączenia Mołdawii do Rumunii Gagauzja ma zagwarantowa- 
ną secesję i możliwość samookreślenia w sytuacji zjednoczenia Mołdawii z Rumunią. Stało się to możliwe dzięki długim staraniom gagauskich deputowanym i założeniu ruchu społecznego Gagauz-Halki. Oznaczało to przede wszystkim przerwanie „zimnej wojny” z Kiszyniowem trwającej od października 1990 roku. Rok 2003 przyniósł nieznaczne zmiany w konstytucji Republiki Mołdawii, obejmujące sposobność ogłoszenia autonomii niektórych terytoriów gagauskich (Hatłas, 2009: 246-247).

Edukacja na terenie Gagauzji realizowana jest od przedszkoli aż po poziom uniwersytecki. Na podstawie danych z 2005 roku funkcjonuje tam ponad 56 szkół (na poziomie podstawowym, gimnazjalnym oraz średnim). Nauczanie nie jest prowadzone w rodzimym języku gagauskim, występuje dominacja języka rosyjskiego. Gagauzja posiada program rozwoju języka narodowego, a on sam nauczany jest na każdym szczeblu edukacji, od 1986 roku jako przedmiot fakultatywny, natomiast od 1 września 1989 roku traktowany jest jako przedmiot obowiązkowy od klasy pierwszej do dziewiątej. Obowiązek szkolny obejmuje wszystkie dzieci zamieszkałe na terytorium Gagauzji (Hatłas, 2009: 139-140).

Długotrwały okres „rozproszenia” Gagauzów wywarł ogromny wpływ na edukację w tym rejonie. Przemiany społeczno-polityczne w latach 80. i 90. XX wieku, „jesień ludów”, uruchomiły ogromną chęć utożsamienia się i określenia własnej narodowości. Duży wpływ wywarła polityka Turcji oraz Rosji. Państwa te, w tym rejonie, posiadają duże oddziaływanie na tutejszą ludność (Solak, 2009: 77-83).

Kolejnym ważnym punktem w opisywaniu edukacji gagauskiej jest jej polityczny charakter. W Gagauzji nie występują żadne partie polityczne. Fakt ten wynika przede wszystkim z prawa mołdawskiego, które nie dopuszcza możliwości rejestracji partii regionalnych. W związku z tym, mieszkańcy terenów Gagauzji, zainteresowani chęcią uczestnictwa w polityce, wchodzą zazwyczaj do partii ogólnokrajowych. Ma to swoje przełożenie na rozwój edukacji w Gagauzji, przede wszystkim w sytuacji przegłosowania ustaw, mających duże znaczenie, dla uczniów gagauskich szkół (Oleksy, 2013: 281).

Sytuacja społeczna i geopolityczna często nie stwarza odpowiednich warunków dla rozwoju szkolnictwa. Jednak mimo wielu tych trudności i niepowodzeń poziom nauczania jest wysoki.

\section{Jedyny taki uniwersytet - znaczenie współpracy turecko-gagauskiej}

Jedna czwarta mieszkańców Mołdawii przebywa za granicą. Wśród nich są także Gagauzi, którzy wyjeżdżają do Turcji „za chlebem” lub, jak się oficjalnie mówi, „na nagraną pracę”. Wpływy Turcji w Gagauzji są bardzo silnie akcentowane. 
Przykładem może być uniwersytet w Komracie - jedyny uniwersytet na świecie z filologią gagauską. Uniwersytet w Komracie jest powodem do dumy mieszkańców Gagauzji. Studiują na nim nie tylko Gagauzi, ale także Turcy i Bułgarzy. Studia w Komracie są bardzo tanie, przez co są atrakcyjne i często wybierane. Dyplom uniwersytetu w Komracie uznawany jest tylko w Mołdawii oraz Turcji (Sierakowska, 2014: 133).

Komracki Uniwersytet Państwowy powstał w 1991 roku. Początek uczelni przypominał bardziej powstanie szkoły podstawowej czy gimnazjum aniżeli uczelni wyższej. Przeważała głównie skromność na nowo powstałej uczelni; przykładem może być kadra naukowo-dydaktyczna złożona przede wszystkim z nauczycieli pobliskich szkół. Zajęcia prowadzone są w języku rosyjskim. Według danych z 2006 roku na uczelni studiowało 2,6 tys. studentów. Uczelnia składa się z czterech wydziałów: rolniczego, prawa, kultury narodowej, ekonomicznego oraz 17 katedr. Uniwersytet w Komracie nie posiada żadnego oficjalnego statusu narodowej uczelni, mimo to jest on chwalony przez wszystkich Gagauzów i po części uznawany za symbol wielkiej intelektualnej Gagauzji. Uniwersytet stał się także symbolem walki politycznej, jaka toczy się od wielu lat. Ma ona podłoże w stosunkach stolicy Gagauzji - Komratem z Kiszyniowem, który coraz bardziej dąży do zmiany statusu Uniwersytetu i przeniesienia go do stolicy Mołdawii (Hatłas, 2009: 142-144).

Uniwersytet w Komracie wykształcił tysiące studentów, jednak jego dyplom nie jest uznawany przez międzynarodową społeczność akademicką. Jedynym krajem, prócz Mołdawii, uznającym dyplom uczelni w Komracie jest Turcja. Dobre stosunki Gagauzji i Turcji są bardzo silnie zakorzenione w lokalnej społeczności, przede wszystkim za sprawą pomocy Turcji na płaszczyźnie gospodarczej. Jako przykład podam udzieloną przez rząd turecki w 1998 roku pożyczkę w wysokości 15 mln dolarów, przeznaczoną w całości na budowę wodociągu w Gagauzji. Turcja widzi w Gagauzji partnera biznesowego, gdyż dzięki współpracy z gagauskimi firmami tureckim przedsiębiorcom otwierają się drzwi do rosyjskiego rynku oraz częściowo na rynki Europy Wschodniej. Turcja akcentuje przynależność etniczną (m.in. wspólna rodzina języków tureckich), jednak nie staje się ona tak ważna jak przynależność gospodarcza (Hatłas, 2009: 170-171). Także uczelnie w Turcji stają się być bardziej przychylne dla młodzieży gagauskiej, chętnej podjąć studia w Turcji. Dlatego każdego roku akademickiego wolne są 24 miejsca na wszystkie uczelnie wyższe w Turcji. Młodzi ludzie chcący podjąć studia w Turcji są zwolnieni z opłat za naukę. Współcześnie wielu Gagauzów nie identyfikuje się z państwem mołdawskim. Turcja jest zatem coraz bardziej atrakcyjna. 


\section{Naddniestrze - zbuntowane, nieistniejące państwo}

Podzielam opinię Roberta Rajczyka, iż Republika Mołdawii jest bardzo ciekawym obiektem badań politologicznych. Rozpad Związku Socjalistycznych Republik Radzieckich dał w pewien sposób impuls dążeniu wielu obszarów byłego Związku Radzieckiego do procesów narodowościowych. Przykładem może być Krym na Ukrainie, Abchazja i Osetia Płd. w Gruzji. Jednak to na obszarze dzisiejszej Mołdawii procesy emancypacyjno-narodowościowe mają szczególne znaczenie we współczesnej Europie (Rajczyk, 2013: 235-236).

Naddniestrzańska Republika Mołdawska to region autonomiczny, wchodzący w skład Republiki Mołdawii, ze stolicą w Tyraspolu. Deklarująca niezależność od władz w Kiszyniowie od 1990 roku, ogłosiła niepodległość 28 sierpnia 1991 roku. $\mathrm{Na}$ arenie międzynarodowej uznawana przez podobne sobie quasi-państwa takie jak: Abchazję, Osetię Płd. Naddniestrze w porównaniu z Gagauzją posiada cechy w pełni uzasadniające suwerenność państwa, takie jak: terytorium (obszar znajdujący się na lewym brzegu Dniestru oraz prawobrzeżne miasto Bendery), ludność i język - na całym terytorium Naddniestrza dominuje język rosyjski (Solak, 2009: 48-49).

Edukacja w Naddniestrzu silnie związana jest z wpływami rosyjskimi i przynależnością historyczną, językową oraz kulturową do Rosji. Lata 90. XX wieku to dla Naddniestrza etap budowania własnej narodowej autoidentyfikacji, przejawiający się coraz szerzej rusocentryzmem jako „lingua franca”. Rusocentryzm silnie jest akcentowany w oświacie i szkolnictwie. Wszystkie przedmioty nauczane są w języku rosyjskim. Nauczanie w Naddniestrzu coraz silniej związane jest $\mathrm{z}$ intensywną kampanią propagandową. Rząd Naddniestrzańskiej Republiki Mołdawskiej postarał się o zachowanie mechanizmu społecznej ochrony, odziedziczony po ZSRR. Ma to zapewnić przede wszystkim poparcie partii rządzącej oraz odejście od identyfikacji rumuńskojęzycznej Besarabii (Solak, 2009: 77-83).

W związku z tym szkolnictwo naddniestrzańskie propaguje wychowanie patriotyczne, a także wybrane elementy wychowania socjalistycznego. Kampania propagandowa daje zamierzone efekty, także w systemie edukacji. Przykładem może być sprawa z lat 2004-2006, kiedy rodzice dzieci uczących się w Naddniestrzu zakwestionowali likwidację szkół prowadzących zajęcia w języku mołdawskim. Ustawa z roku 1992 zakłada używanie języka mołdawskiego, ale jedynie w zapisie cyrylicą. Nowelizacja ustawy w 1994 roku głosi, iż używanie alfabetu łacińskiego m.in. w naddniestrzańskim systemie edukacyjnym jest wykroczeniem administracyjnym. Europejski Trybunał Praw Człowieka zareagował na istniejące „nielegalne” ustawy i skazał Rosję. Powodem jest pogwałcenie prawa w dostępie do edukacji w Naddniestrzu. Trybunał w Strasburgu podjęcie takiej 
decyzji tłumaczył przede wszystkim popieraniem separatystycznego reżimu, poprzez wspieranie militarne czy gospodarcze przez Rosję. Natychmiastowa reakcja Moskwy daje nam ogląd, jak silnie kształcenie w Naddniestrzu związane jest z sytuacją polityczną (www.lex.pl/czytaj/-/artykul/strasburg-rosja-winna-naru szenia-prawa-do-edukacji-w-naddniestrzu?refererPlid=68467180 (dostęp: 30.10 . 2014).

Duże znaczenie w Naddniestrzu ma Tyraspolska Wyższa Szkoła dla Politycznych Liderów Che Guevary. Powstała w Tyraspolu, odgrywa jedną zasadniczą rolę - ma być antidotum na „kolorowe rewolucje”. Geneza i znaczenie powstania tejże szkoły to tajemnica ściśle chroniona przez władzę w Tyraspolu, a w samym Internecie trudno o jakąkolwiek informację $\mathrm{z}$ tego zakresu. Edukacja, podobnie jak i samo quasi-państwo, przypomina skansen komunizmu. Silnie akcentowane symbole minionej epoki: „sierp i młot”, pomniki Lenina i Stalina, antyamerykanizm, zjednoczeniowe hasła: „Cała Nasza Nadzieja w Rosji. Tylko Rosja nam pomoże", wyraźnie pokazują, jaki kierunek obrał rząd w Naddniestrzu.

\section{Quo vadis Moldawia?}

W Mołdawii od 2009 roku prowadzona jest reforma edukacji, przejawiająca się $\mathrm{w}$ restrukturyzacji szkolnictwa podstawowego oraz średniego, wprowadzeniem nowego programu nauczania i remontem infrastruktury szkolnej. Jednakże Mołdawianie nie są do końca przekonani o słuszności przeprowadzanych refom. Spowodowane jest to głównie, szerzącą się korupcją i brakiem środków finansowych.

Wybory parlamentarne, przeprowadzone 30 listopada 2014 roku, wyraźnie pokazują podział narodowościowy w Mołdawii. Droga tego kraju do Unii Europejskiej może być znacząco zahamowana. Mimo możliwości utworzenia koalicji rządowej, składającej się z Partii Demokratycznej i proeuropejskiej Partii Liberalnej, poparcie dla partii silnie akcentujących integrację Mołdawii z Unią Europejską uległo zmniejszeniu $\mathrm{w}$ porównaniu z poprzednimi wyborami (Całus, 2014).

\section{Literatura}

Ciobanu V. (2013). „Zgubione” państwo pomiędzy Wschodem a Zachodem. [W:] M. Kosienkowski (red.). Spotkania polsko-mołdawskie. Księga poświęcona pamięci Profesora Janusza Solaka. Lublin.

Hatłas J. (2009). Gagauzja i Gagauzi - historia oraz wspótczesność. Poznań. 
Oleksy P. (2013). Życie polityczne w Gagauzji. [W:] M. Kosienkowski (red.). Spotkania polsko-mołdawskie. Księga poświęcona pamięci Profesora Janusza Solaka. Lublin.

Pieńkowski J. (2013). Dlaczego Rumunia zawsze będzie kochać Mołdawię. [W:] M. Kosienkowski (red.). Spotkania polsko-mołdawskie. Księga poświęcona pamięci Profesora Janusza Solaka. Lublin.

Rajczyk R. (2013). Republika Mołdawii: jedno państwo, dwa systemy. [W:] M. Kosienkowski (red.). Spotkania polsko-mołdawskie. Księga poświęcona pamięci Profesora Janusza Solaka. Lublin.

Sierakowska J. (2014). „Mołdawianie w kosmos nie lietajut biez wina”. Gliwice.

Sineava-Pankowska N. (2009). Mołdawskie multikulti. „Nowa Europa Wschodnia. Dwumiesięcznik poświęcony Europie Wschodniej i Azji Centralnej" nr 3-4.

Solak J. (2009). Mołdawia - republika na trzy pęknięta. Historyczno-społeczny, militarny i geopolityczny wymiar „zamrożonego konfliktu”o Naddniestrze. Toruń.

\section{Źródła internetowe}

Całus K. (2014). Mołdawia: umiarkowany sukces partii proeuropejskich", www.osw.waw.pl/pl/ publikacje/analizy/2014-12-03/moldawia-umiarkowany-sukces-partiiproeuropejskich (dostęp: 10.12.2014).

www.lex.pl/czytaj/-/artykul/strasburgrosja-winna-naruszenia-prawa-do-edukacji-wnaddniestrzu? refererPlid=68467180 (dostęp: 30.10 .2014$)$.

www.jozefdarski.pl/6974-kwestia-besarabska-1993 (dostęp: 10.11.2014).

\section{Ethnic and National Divisions in the Republic of Moldova. The Impact and Significance of Education in the Two Separate States - Gagauzia and Transnistria}

\section{Summary}

In his article the author draws attention to the fact that the Republic of Moldova regained its independence from the Soviet Union in 1991. Twenty-five years have passed since that event, and a growing number of experts dealing with the issues of the former Soviet republics are pointing out, that the country has been in a deadlock for years. Moldova's path "towards normality" is increasingly resembling a catalog of failures, mutual accusations and grievances. This small country in South-Eastern Europe is the perfect example of a clash of enormous economic, political and socio-cultural forces.

For many citizens the fall of the Moldavian Soviet Socialist Republic meant a new hope, a chance for change in a country liberated from the influence of Moscow, and an end of a certain era. The reality, however, turned out to be much more brutal. The separation and the resulting declaration of independence from the Soviet Union by the Republic of Moldova raised many often quite controversial questions. The Declaration of Independence of the Republic of Moldova adopted on 27 August 1991 stirs the most controversy. It gradually became "an end in itself". It caused a very rapid cooling of the civic enthusiasm, and strongly shaped the conflict between the increas- 
ingly powerful Neo-communist party and the pro-Kremlin parties. The result was a return of the old nomenclature, even from before the establishment of the independent Republic of Moldova in $1991^{1}$.

Education in Moldova is therefore strongly tied with ethnic identity and dual nationality. Romanian schools in Moldova functioned until 1865 (the Crimean War). The closure of these schools was a result of the intensified process of Russification. Today the Romanian language is present in schools and is a compulsory subject. Due to the progressing Russification, in the 1970s there was one class with the Russian language of instruction for every three classes with the Moldovan language of instruction.

In reference to the views of Natalia Sineaeva-Pankowska the author describes three models of national identity, which are clashing in Moldova and have an impact on contemporary education in Moldova: a) pan-Romanianism: Romania este partia mea. In the Moldovan version it is built on the basis of ethnic and linguistic ties. The Moldovan language is treated as a dialect, directly related to the Romanian language. In turn the Moldovans are treated as a constituent part of the Romanian people; b) Panslavism - Soviet identity: Very strongly emphasized in the years 1940-1989, particularly by the Communists, and associated with the establishment of the Moldavian Soviet Socialist Republic. Its main foundation was the identification of the inhabitants of Moldova with the rest of the territory of the Soviet Union and a sense of belonging to the Soviet culture and education. Currently this model of identity can be observed most strongly in Transnistria. Heavily intensifying Russification of the Moldovan education; c) Moldovenism: "A Moldavian Moldova" or "One nation, two states". It atrongly emphasizes Moldova's national and ethnic separateness, based on historical distinctness (the figure of Stephen the Great) as well as socio-cultural development. In principle Moldovenism has two basic types: native and multi-ethnic. The situation is further complicated as the country is internally torn between the East and the West. The most important objective is to protect Moldova's independence and coalesce around the pro-European political course.

In the conclusion it was emphasized, that since 2009 an educational reform has been underway in Moldova. It is manifested in the restructuring of primary and secondary education, the introduction of a new curriculum and the renovation of the school infrastructure. The Moldovans, however, are not entirely convinced as to the validity of the reforms carried out. The parliamentary elections held in 2014, clearly demonstrated the national divisions in Moldova. Moldova's path to the European Union could be significantly hampered. Despite the possibility of the formation of a government coalition consisting of the Democratic Party and the pro-European Liberal Party, the support for parties strongly emphasizing Moldova's integration with the European Union decreased in comparison with the previous elections. 